IP Periodica Polytechnica Civil Engineering

62(4), pp. 1076-1082, 2018

https://doi.org/10.3311/PPci.12010

Creative Commons Attribution (i)

TECHNICAL NOTES

\section{Examination of the Properties of Historical Wrought Iron in Architectural Structures}

\author{
István Vidovszky $^{1 *}$, Jenő Kiss ${ }^{1}$
}

Received 27 January 2018; Revised 18 April 2018; Accepted 09 May 2018

\begin{abstract}
Wrought iron elements were produced of material with various quality from the ancient times to the early 20th century however played increasingly enhanced roles in the structural stability of buildings up to the modern times when reinforced concrete slabs and ring beams appeared. Wall ties and anchors were responsible for establishing a structural connection between slabs (beams) and walls or in case of vaults, such ties balanced the vertical component of the loads. There were some analyses in the literature on the strength of wrought iron structural elements, mainly bridge elements, manufactured in ironworks. However, there are a few studies only on the mechanical properties of the material of structures, which were manufactured manually in workshops that was typical in case of smaller construction elements. In this study, two types of hardness tests and tensile strength examinations were carried out on wrought iron structural elements taken from Hungarian buildings originating from the $18^{\text {th }}, 19^{\text {th }}$ and early $20^{\text {th }}$ centuries to study the mechanical properties. Additionally, $X$-ray tests were performed to explore some features of manufacturing for the better understanding of the measured values. As a result, some information was gained about the structural analyses of the manually forged wrought iron elements.
\end{abstract}

\section{Keywords}

wrought iron, historic construction elements, manual forging, strength test, state survey

\footnotetext{
1 Department of Construction Technology and Management

Faculty of Architecture,

Budapest University of Technology and Economics

H-1111 Budapest, Müegyetem rkp. 3., Hungary

*Corresponding author, email: ividovszky@ekt.bme.hu
}

\section{Introduction}

It can be assumed that manually forged building structure elements need special handling because of the characteristics of the wrought iron material. [1, 2] In consequence of the material quality of wrought iron construction elements, a wellknown risk emerges about historic structures. While there have been research studies performed, and testing methodologies developed about certain kinds of structures, like wrought iron bridges [3, 9, 12, 13, 19], only a few research work (e.g. the study of Buchwald and Wivel [4]) concerning the methodology to investigate the mechanical properties of smaller wrought iron elements at building structures despite the fact that some of them, like balk irons or arch ties, could play a significant structural role [5].

In this study, no rolled section, but manually forged elements of building structures are analyzed.

The factors and the effects, which influence the mechanical properties of the material such as strength or ductility, both of which can have an impact on the load-bearing capacity, are considered. Data on mechanical properties from the literature (Table 1, Fig. 1) are compared to new measured data. On the bases of the examinations, a better understanding of the state of historic wrought iron building structures became possible.

Table 1 Strengths of wrought iron materials

\begin{tabular}{lcccc}
\hline $\begin{array}{l}\text { Type of the } \\
\text { material }\end{array}$ & $\begin{array}{c}\text { Place of } \\
\text { production }\end{array}$ & Place of use & Age & $T[\mathrm{MPa}]$ \\
\hline $\begin{array}{l}\text { ordinary } \\
\text { wrought iron } \\
\text { bridge } \\
\text { materials }\end{array}$ & - & - & $1863-1922$ & $250-680$ \\
& USA & USA & $\begin{array}{l}1858-\text { early } \\
20^{\text {th }} \text { century }\end{array}$ & $332-458$ \\
& Hungary $^{1}$ & Austria & $1865-1903$ & $323-381$ \\
& & $\begin{array}{c}\text { France and } \\
\text { Belgium }\end{array}$ & $1877-1883$ & $355-389$ \\
& & Bohemia & $1889-1896$ & $332-361$ \\
& & Hungary & $1874-1896$ & $297-428$ \\
\hline
\end{tabular}

Remark: $T=$ tensile strength

Sources: Gordon and Knopf (2005) [3]; Grueber (1863) [6]; Gottgetreu (1881) [7]; Ledebur (1890) [8]; Maurer (1892) [9]; Janke (1895) [10]; Grofcsik (1922) [11]; Nemeskéri (1958) [12]; Papp (1959) [13];

${ }^{1}$ The territory of the late (19 ${ }^{\text {th }}$ century) Hungarian Kingdom 


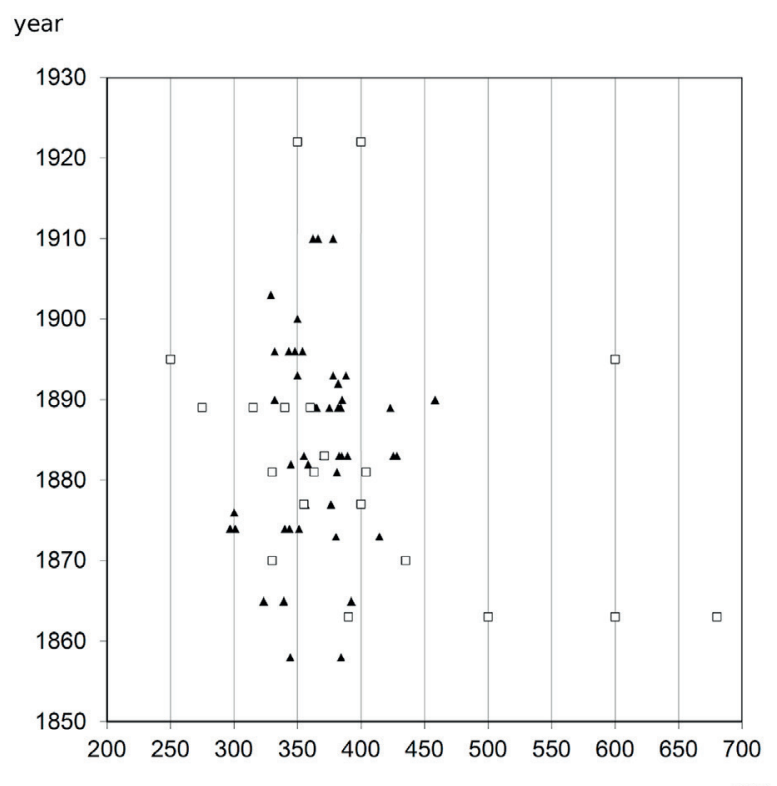

$\mathrm{MPa}$

Fig. 1 Strength of wrought iron taken from $19^{\text {th }}$ century and early $20^{\text {th }}$ century bridge structures (black triangles), and strength of ordinary wrought iron materials (white squares) Sources: Gordon and Knopf (2005) [3]; Grueber (1863) [6]; Gottgetreu (1881) [7]; Ledebur (1890) [8]; Maurer (1892) [9]; Janke (1895) [10]; Grofcsik (1922) [11]; Nemeskéri (1958) [12]; Papp (1959) [13]

\subsection{Historic background}

Wrought iron construction elements have been applied since the Romans. In historic buildings, the main role of these structural elements was to establish a more secure connection at the joints of various structures with a material that has a significant tension strength in contrast with most traditional construction materials but timber. The importance of these wrought iron elements had increased up to the $19^{\text {th }}$ century. Balk irons secured the connection of timber floors to the walls, and wall ties prevented brick walls from separation. Ties were used for anchoring ashlar walls [14] and various iron cramps were used for keeping stone blocks together. Wrought iron straps were applied as parts of the roof structures [15], and wrought iron ringstraps secured the domes in some cases. Arch ties were applied for balancing the horizontal forces of the vaults in case of narrow walls. Initially those were placed at the height of the springing line [16] but from the Baroque on such ties were positioned outside of the extrados of the vaults. The statically calculated and adjustable versions of arch ties appeared in the second half of the $19^{\text {th }}$ century [17]. At the end of the $19^{\text {th }}$ century, a smaller part of structural elements was manufactured by serial production of the iron factories, but a significant part was still produced by manual forging.

\subsection{Goals of the research}

Our goal on the long run is to evaluate a method for in-situ, non-destructive testing of the structural elements in historic buildings to verify their soundness and stability for ongoing use, however this research can be considered only as a pilot with a small numbers of samples.
Table 2 The samples tested

\begin{tabular}{|c|c|c|c|}
\hline Provenance and function & Age & ID & Size $[\mathrm{mm}]$ \\
\hline \multirow{2}{*}{$\begin{array}{l}\text { Gyula fortress, pieces of ties } \\
\text { to hang brown meat }\end{array}$} & \multirow{2}{*}{$18^{\text {th }}$ century } & $\mathrm{G} 1 / 1$ & $1025 \times 65 \times 27$ \\
\hline & & $\mathrm{G} 1 / 2$ & $980 \times 65 \times 25$ \\
\hline $\begin{array}{l}\text { Sugarworks Hatvan }{ }^{\text {b }} \text {, wall tie } \\
\text { (looped back piece) }\end{array}$ & 1889 & $\mathrm{H} 1 / 1$ & $370 \times 50 \times 7$ \\
\hline $\begin{array}{l}\text { Sugarworks Hatvan, wall tie } \\
\text { (medium piece) }\end{array}$ & 1889 & $\mathrm{H} 1 / 2$ & $1063 \times 60 \times 10$ \\
\hline \multirow{2}{*}{$\begin{array}{l}\text { Máriabesnyő (Gödöllő), altar- } \\
\text { screen element }^{c}\end{array}$} & \multirow{2}{*}{$1768-71$} & $\mathrm{M} 1 / 1$ & $630 \times 28 \times 8$ \\
\hline & & $\mathrm{M} 1 / 2 \mathrm{a}-\mathrm{b}$ & $520 \times 28 \times 8$ \\
\hline $\begin{array}{l}\text { Zsámbék, late Zichy-castled, } \\
\text { balk iron (horizontal part) }\end{array}$ & \multirow{2}{*}{ around 1905} & $\mathrm{Z} 1 / 1$ & $l=810 \quad d=24$ \\
\hline $\begin{array}{l}\text { Zsámbék, late Zichy-castle }{ }^{\mathrm{d}} \\
\text { balk iron (vertical part) }\end{array}$ & & $\mathrm{Z} 1 / 2$ & $l=410 \quad d=24$ \\
\hline \multirow{2}{*}{$\begin{array}{l}\text { Zsámbék, late Zichy-castle } \\
\text { wall tie }\end{array}$} & \multirow{2}{*}{ around 1710} & $\mathrm{Z} 2 / 1$ & $850 \times 25 \times 25$ \\
\hline & & $\mathrm{Z} 2 / 2$ & $850 \times 25 \times 25$ \\
\hline
\end{tabular}

Remark: $l=$ length; $d=$ diameter

a The samples originate from the $18^{\text {th }}$ century erected part of the Gothic castle, originally built in the $15^{\text {th }}$ century (Hungary, Békés County).

b The first building of the sugarworks at Hatvan (Hungary, Heves County, city of Hatvan), built at the end of the $19^{\text {th }}$ century (1889).

c The sample originates from the Roman Catholic parish-church at GödöllöMáriabesnyő (Hungary, Pest County). The church was built as the family temple of the Grassalkovich family between 1768 and 1771 .

d The castle of the Zichy family built at the place of the medieval fortress at Zsámbék (Hungary, Pest County) in the early $18^{\text {th }}$ century. The castle was completed with a new floor in the first years of the $20^{\text {th }}$ century. Before the years of the present restoration, the building was used by the Apor Vilmos Catholic College.

As a first step, we made an attempt to determine the material properties of manually forged wrought iron samples of various $18^{\text {th }}, 19^{\text {th }}$ and early $20^{\text {th }}$ century structural elements from demolished buildings or removed building structures. The material samples are listed by their geometric dimensions and provenance in Table 2. As a second step, the collected samples were investigated to reveal typical phenomena related to variations in the material strength of the structural parts manufactured manually. To this end, X-ray, hardness, and tensile tests were carried out on manually manufactured building structure elements of various ages.

\section{Methods}

\subsection{X-ray tests}

$\mathrm{X}$-ray images render an informative picture about the structure and the flaws of the material. This enables us to see whether the sample is to be considered as homogenous ingot iron (mild steel) or as fibrous wrought iron material. We applied X-ray tests because we were about to evaluate a non-destructive testing method, which can be used at small building construction elements where the size of the element does not allow to take samples for micrographs.

$\mathrm{X}$-ray images were shot by a portable X-ray unit. The wrought iron samples were put on an X-ray film laid onto a lead plate and they were exposed to a thickness-dependent beam power 


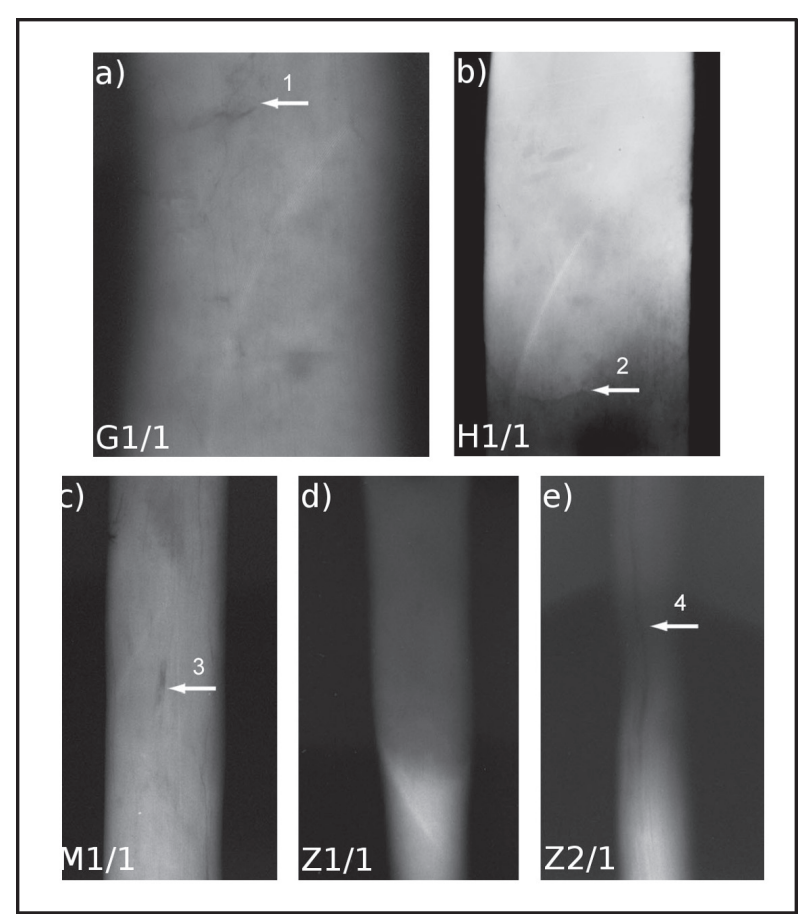

Fig. 2 X-ray images: a) Gyula fortress, pieces of ties to hang brown meat; b) sugarworks at Hatvan, wall tie brace (looped back piece); c) Máriabesnyő (Gödöllö), Roman Catholic church, altar-screen element; d) Zsámbék, Zichycastle, balk iron (vertical element); e) Zsámbék, Zichy-castle, arch-tie

for specified times. The image depicting the material originating from Gyula fortress (G1/1) shows clearly thin, longitudinal slag inclusions indicating a structure characterizing wrought iron and a nearly transversal crack-like line indicating possibly a forge welded lengthening joint (Fig. 2/a - arrow 1). The material of the wall tie of the demolished sugar works at Hatvan (H1/1) is homogenous. It shows only the place of the welding of the bent back hook (Fig. 2/b - arrow 2). The X-ray image of the altar screen element at Máriabesnyő (M1/1) clearly shows the longitudinal black slag inclusion fibres (Fig. 2/c - arrow 3). According to the image the material (Z1/1) of the balk iron manufactured in the early $20^{\text {th }}$ century is homogenous (Fig. $2 / \mathrm{d}$ ). On the contrary, the wavy thin black stripes in the material of the arch-tie (Z2/1) originating from the $18^{\text {th }}$ century demonstrate a wrought iron structure (Fig. 2/e - arrow 4).

The results show that the material of the wall tie of the sugar factory at Hatvan and the balk iron found at Zsámbék is ingot iron (mild steel). The material of the other samples is wrought iron. The inhomogeneity of the material and its fibrous structure are clearly shown on the X-ray images.

\subsection{Hardness tests}

Hardness tests are not adequate to determine the exact strength of wrought iron materials due to their inhomogeneity, but the changes in the structure can be characterised by the large dispersion of hardness values.

Hardness (Leeb value) was basically measured by a dynamic method using Equotip 2 portable digital hardness tester. Assuming uniform distribution on the surface sections, seven
Table 3 Results of the hardness tests on the surface

\begin{tabular}{|c|c|c|c|}
\hline Material & Measurement & $L_{D}$ I. aver. & $T_{e}[\mathrm{MPa}]$ \\
\hline \multirow[t]{3}{*}{ Gyula (G1/1) } & minimum & 366 & 386 \\
\hline & maximum & 490 & 702 \\
\hline & average total & 404 & 469 \\
\hline \multirow[t]{3}{*}{ Hatvan $(\mathrm{H} 1 / 1)$} & minimum & 367 & 386 \\
\hline & maximum & 416 & 499 \\
\hline & average total & 394 & 446 \\
\hline \multirow[t]{3}{*}{ Máriabesnyő (M1/1) } & minimum & 305 & 281 \\
\hline & maximum & 345 & 347 \\
\hline & average total & 310 & 281 \\
\hline \multirow[t]{3}{*}{ Zsámbék (Z1/1) } & minimum & 334 & 327 \\
\hline & maximum & 353 & 360 \\
\hline & average total & 346 & 347 \\
\hline \multirow[t]{3}{*}{ Zsámbék (Z2/1) } & minimum & 395 & 449 \\
\hline & maximum & 435 & 549 \\
\hline & average total & 415 & 496 \\
\hline
\end{tabular}

Remark: $T_{e}=$ estimated tensile strength; $L_{D} I$. aver. = average of seven measurements of hardness value measured on the surfaces of the sample with the digital hardometer equipped with (normal) instrument head of D type.

measurements per each were carried out, from the average of which the instrument calculated automatically the approximate values of tensile strength. As a first step, the values were measured on the polished surface of the samples. The Leeb values were measured directly by the digital hardness tester, the $T_{e}$ values were estimated by the help of the given calibration information from the producer of the instrument. Table 3 shows the measured minimum, maximum and the total average values of all hardness tests carried out on the sample out of the averages of the hardness values measured on the surface sections.

Following surface hardness tests, rectangular prism-shaped test pieces were taken from the middle of the body of each sample (Fig.3). In this case, hardness values were measured on the surface of the test pieces (intermediate plane of the original samples) by a portable digital hardness tester and a manual Brinell-hardometer (Poldi hammer) as well. Assuming uniform distribution on the surface of the three test pieces, seven measurements using the digital hardometer and three measurements using the Poldi hammer were carried out on each one. Tests were repeated on a standard mild steel reference specimen of EN 10025 S235JRG2 quality as well

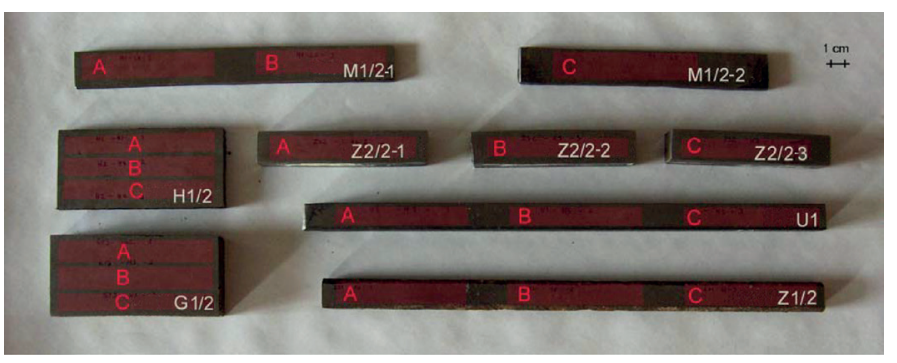

Fig. 3 Prism-shaped test pieces taken from the sample structural elements 
Table 4 Hardness test results measured two different ways on intermediate plane

\begin{tabular}{|c|c|c|c|c|c|}
\hline \multirow[t]{2}{*}{ Material } & \multirow[t]{2}{*}{ Location } & \multicolumn{2}{|c|}{$L_{D}$ II. } & \multicolumn{2}{|c|}{ Poldi hammer } \\
\hline & & $L_{D}$ aver. & $T_{e}[\mathrm{MPa}]$ & HB aver. & $T_{e}[\mathrm{MPa}]$ \\
\hline \multirow{3}{*}{ Gyula (G1/2) } & A & 362 & 377 & 117 & 354 \\
\hline & B & 351 & 357 & 112 & 338 \\
\hline & $\mathrm{C}$ & 354 & 363 & 114 & 346 \\
\hline \multirow{3}{*}{ Hatvan $(\mathrm{H} 1 / 2)$} & A & 346 & 347 & 125 & 370 \\
\hline & B & 377 & 410 & 141 & 414 \\
\hline & $\mathrm{C}$ & 365 & 383 & 140 & 410 \\
\hline \multirow{3}{*}{$\begin{array}{l}\text { Máriabesnyő } \\
(\mathrm{M} 1 / 2)\end{array}$} & A & 395 & 449 & 158 & 466 \\
\hline & $\mathrm{B}$ & 388 & 433 & 140 & 410 \\
\hline & $\mathrm{C}$ & 386 & 429 & 125 & 370 \\
\hline \multirow{3}{*}{$\begin{array}{l}\text { Zsámbék } \\
(Z 1 / 2)\end{array}$} & A & 346 & 347 & 126 & 374 \\
\hline & B & 342 & 340 & 111 & 334 \\
\hline & $\mathrm{C}$ & 339 & 333 & 110 & 330 \\
\hline \multirow{3}{*}{$\begin{array}{l}\text { Zsámbék } \\
(\mathrm{Z} 2 / 2)\end{array}$} & A & 375 & 403 & 133 & 396 \\
\hline & $\mathrm{B}$ & 375 & 403 & 130 & 390 \\
\hline & $\mathrm{C}$ & 360 & 373 & 117 & 354 \\
\hline \multirow{3}{*}{$\begin{array}{l}\text { S235JRG2 } \\
\text { (U1) }\end{array}$} & A & 370 & 393 & 126 & 374 \\
\hline & B & 389 & 436 & 129 & 386 \\
\hline & $\mathrm{C}$ & 373 & 400 & 130 & 390 \\
\hline
\end{tabular}

Remark: $T_{e}=$ estimated tensile strength; $L_{D}$ II. $=$ hardness value measured on an intermediate plane with the digital hardometer equipped with (normal) instrument head of $D$ type; $L_{D}$ aver. $=$ average of the $L_{D}$ values / test-piece; HB aver. $=$ Average of the Brinell hardness values / test-piece
Brinell values are settled on the basis of the calibration tables of the instrument, strength values are estimated on the bases of an experimental formula to convert Brinell values to strength data.

The results are summarised in Table 4 .

\subsection{Tensile tests}

Having finished the hardness tests, standard cylindrical test pieces of $8 \mathrm{~mm}$ diameter and $125 \mathrm{~mm}$ length were taken from the four samples (Gyula - G1, Hatvan - H1, Zsámbék - Z1 and Z2), while for the material of Máriabesnyő (M1) tensile test specimens of $8 \times 15 \times 120 \mathrm{~mm}$ size were taken. The tensile tests on the pieces were carried out by an electro-mechanical testing machine of $100 \mathrm{kN}$ measuring limit. Tests were repeated on a standard mild steel reference specimen of EN 10025 S235JRG2 quality as well. We measured strain as well, however the values are not informative enough, because in consequence of the impurities in the sample materials some of the cross sections were torn in more phases. The measured values are shown in Table 5. The stress-strain diagrams can be seen on Figure 4.

Table 5 Comparison of the results

\begin{tabular}{|c|c|c|c|c|c|c|c|}
\hline \multirow{2}{*}{ Material } & \multirow{2}{*}{ Location } & \multicolumn{3}{|c|}{$T_{e}[\mathrm{MPa}]$} & \multirow[b]{2}{*}{$T_{\text {yield }}[\mathrm{MPa}]$} & \multirow{2}{*}{$T_{m}[\mathrm{MPa}]$} & \multirow{2}{*}{$\varepsilon[\%]$} \\
\hline & & $L_{D} \mathrm{I}$. & $L_{D}$ II. & Poldi & & & \\
\hline \multirow{4}{*}{ Gyula (G1) } & A & & 377 & 354 & 243 & 345 & 35,2 \\
\hline & B & & 357 & 338 & 243 & 340 & 38,6 \\
\hline & $\mathrm{C}$ & & 363 & 346 & 251 & 345 & 37,7 \\
\hline & average & 469 & 366 & 346 & 246 & 343 & 37,2 \\
\hline \multirow{4}{*}{ Hatvan (H1) } & A & & 347 & 370 & 295 & 385 & 28,7 \\
\hline & B & & 410 & 414 & 295 & 406 & 23,7 \\
\hline & $\mathrm{C}$ & & 383 & 410 & 294 & 383 & 26,4 \\
\hline & average & 446 & 380 & 398 & 295 & 391 & 26,3 \\
\hline \multirow{4}{*}{$\begin{array}{l}\text { Mária- besnyő } \\
\text { (M1) }\end{array}$} & $\mathrm{A}$ & & 449 & 466 & 344 & 439 & 19,1 \\
\hline & B & & 433 & 410 & 379 & 482 & 18,8 \\
\hline & C & & 429 & 370 & 397 & 475 & 18,4 \\
\hline & average & 281 & 437 & 415 & 373 & 465 & 18,8 \\
\hline \multirow{4}{*}{ Zsámbék (Z1) } & $\mathrm{A}$ & & 347 & 374 & 278 & 365 & 39,5 \\
\hline & B & & 340 & 334 & 298 & 363 & 38,4 \\
\hline & $\mathrm{C}$ & & 333 & 330 & 284 & 367 & 38,5 \\
\hline & average & 347 & 340 & 346 & 287 & 364 & 38,8 \\
\hline \multirow{4}{*}{ Zsámbék (Z2) } & A & & 403 & 396 & 174 & 295 & 39,6 \\
\hline & B & & 403 & 390 & 195 & 312 & 31,2 \\
\hline & $\mathrm{C}$ & & 373 & 354 & 169 & 302 & 39,5 \\
\hline & average & 496 & 393 & 380 & 179 & 303 & 36,8 \\
\hline \multirow{4}{*}{ SJRG235 (U1) } & A & & 393 & 374 & 293 & 421 & 36,5 \\
\hline & B & & 436 & 386 & 275 & 425 & 36,9 \\
\hline & C & & 400 & 390 & 284 & 422 & 36,2 \\
\hline & average & - & 410 & 383 & 284 & 423 & 36,5 \\
\hline
\end{tabular}

Remark: $T_{e}=$ estimated tensile strength; $T_{\text {yield }}=$ yield strength $T_{m}=$ measured tensile strength; $\varepsilon=$ measured strain; $L_{D}=$ hardness value measured with the digital hardometer equipped with (normal) instrument head of $D$ type: I. = on the surface, II. = on an intermediate plane; Poldi-hammer measurement; aver. = average value; loc. $=$ location 
1.

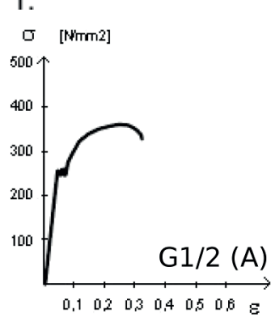

\section{2.}

o [Nimrin]

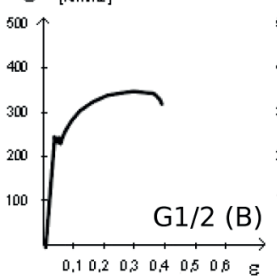

3.

口 [Nimr2]

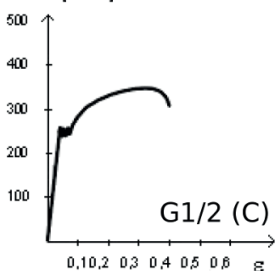

4.

- $\quad$ [Nmm2]

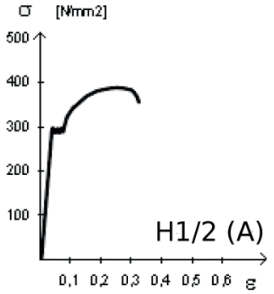

5.

- [N(NTrm2]

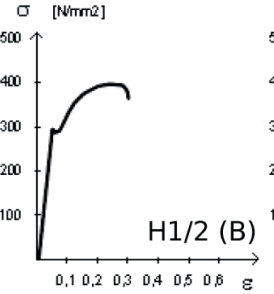

6.

[. [Nimra]

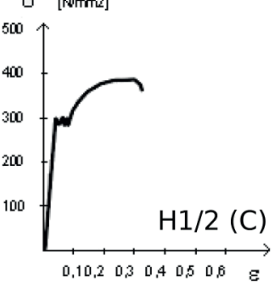

7.

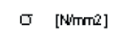

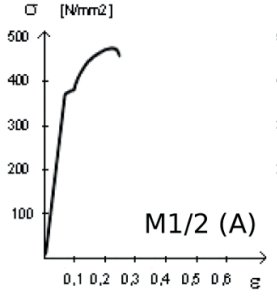

8.

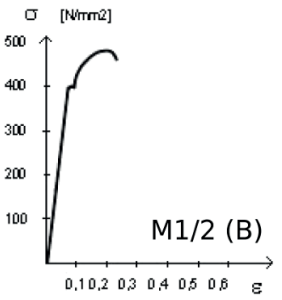

9.

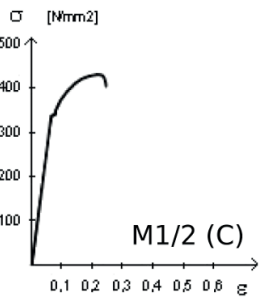

10.

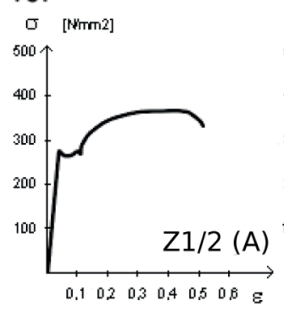

11.

o [N/m2]

$500 \uparrow$

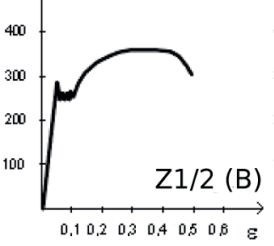

[ [Nmm2]

500

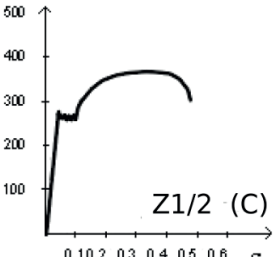

13.

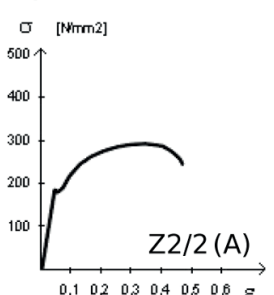

16.

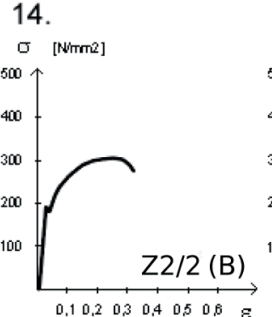

17.

15.

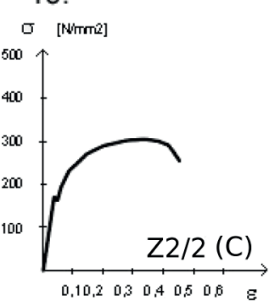

18.
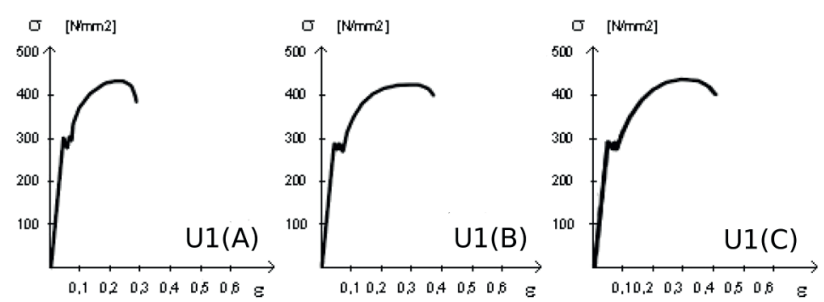

Fig. 4 Stress-strain diagrams of the tensil tests

\section{Results}

Tensile strength values calculated from the hardness test, data measured on the surface and on the intermediate plane were compared to each other and to the values obtained from tensile tests. Comparison of the tensile strength values obtained by various methods is shown in Table 5 .

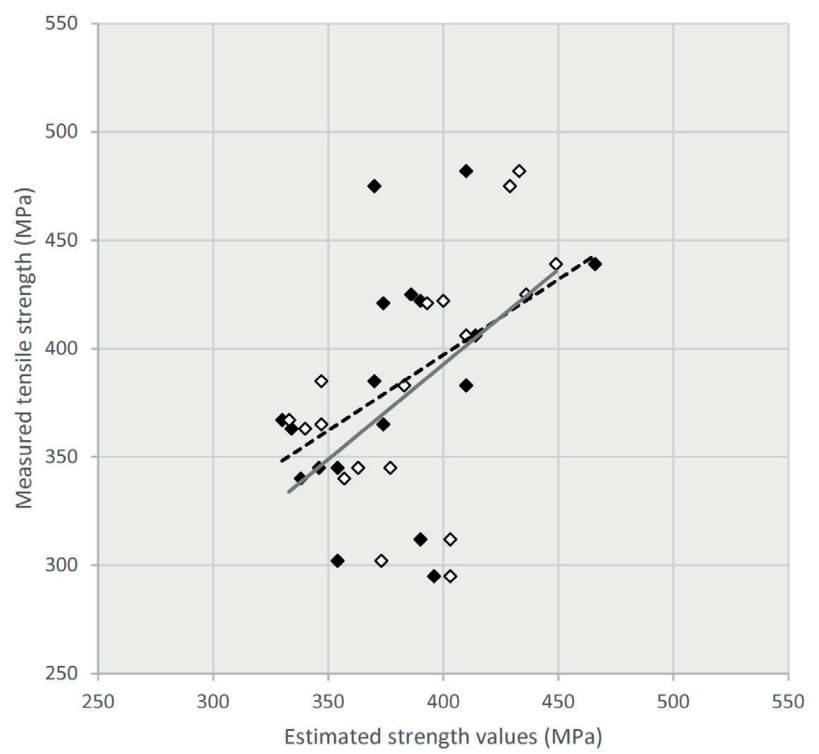

Fig. 5 Relation of estimated and measured strength in case of digital hardometer (black squares - solid line) and Poldi-hammer (white diamonds dashed line) measurements.

There is no interpretable correlation $(r=-0.85 ; p>0.25)$ between the tensile strength values estimated on the basis of the hardness tests measured on the surface of the samples and the ones measured directly by tensile tests. There is no correlation, either, between the hardness values measured on the surface and on the intermediate plane even in case of the same specimen and measuring method $(r=-0.35 ; p>0.25)$. Our test results confirm that in case of manually forged iron the strength of the material cannot be estimated from the surface hardness with adequate accuracy. Solely the fact of inhomogeneity can be concluded from test results. However, the strength values determined directly (tensile test) are in a stronger correlation with strength values estimated from the LD hardness values measured on the intermediate plane $(r=0.57 ; p=0.01)$. The correlation is even stronger without the specimen Z2 $(r=$ $0.86 ; p=0.01)$ or in case of the Poldi measurement $(r=0.79 ; p$ $=0.01)$. The material of the arch tie of Zsámbék (Z2), where the tensile strength is lower by about $100 \mathrm{~N} / \mathrm{mm}^{2}$ than the value expected from the hardness test, provides outlier data. (Fig. 5)

Regarding the two kinds of hardness measurement methods applied on the intermediate plane of the samples it can be stated that the two sets of data show a relatively strong correlation $(r=0.77 ; p=0.01)$.

\section{Discussion}

Most present testing methods for steel materials and structures are developed for testing homogeneous material samples. The material of manually forged building structures is not homogenous. On the one hand the base material of the structural elements is inhomogeneous wrought iron in many cases, on the other hand the heating and forming processes of forging cause several kinds of inhomogeneity (e.g. hardening, carburization, decarburization), accompanied by differences 
of material properties in the different locations of the sample. These factors should be considered in the measurements and in the evaluation process.

The type of the base material (mild steel or wrought iron) and the places of material failures can be revealed by X-ray tests. In case of historic mild steel materials, the lack of ductility is usually caused by Sulphur or phosphorus contamination $[3,18]$ that can be detected by e.g. optical emission spectroscopy. The inhomogeneity of the material of manually forged elements of building structures in case of mild steel is generally caused by the working process, which - apart from the directly impacted areas, like e.g. the decorated endings of a rod - effects mainly the surface zone. In this case, the strength of the sample can be estimated based on hardness tests on properly selected test spots of the sample, with care at the selection and elaborating of the spot not jeopardizing the stability of the structure either. Although the hardness tests on the surface do not yield adequate information about the strength of the sample in case of mild steel, it is possible to prepare a spot a couple of millimetres under the surface (as an intermediate plane) where it is possible to estimate characteristic strength values from the measured hardness values. The above statement is seemed to be supported by the correlation between the strength values of tensile tests and the strength values estimated from the hardness tests measured by a digital hardness tester and by manual Brinell hardometer (Poldi-hammer), however only a larger number of samples could support this statement properly.

In case of wrought iron, the lack of ductility can be caused by slag inclusions reducing the area of the cross-sections and the penetrating corrosion. Both of these failures can be detected by $\mathrm{X}$-ray tests. If nothing refers to any of the failures mentioned, the load-bearing capacity of the structure is very likely appropriate for ongoing service at unaltered loads, although the strength of the material cannot be estimated from the hardness tests in this case. Because of inhomogeneity, there is no exact relation between the mechanical properties of the different parts of the sample. In case the load-bearing capacity of a wrought iron structure is reduced by forge welded joints, corrosion, or slag inclusion blocking the area of the cross-sections, it is necessary to reveal the weakest cross-section for making decision about a structural element. There is no general treatment to be recommended because the decision about the future of the structure is influenced by the circumstances of use (e.g. condition of the structure, loads, change of loads, etc.).

\section{Conclusions}

Because of the small number of the samples, this study has to be considered as a pilot research, consequently on the bases of its results it is challenging to establish far-reaching conclusion, however it can be considered as a step forward revealing the material quality of wrought iron parts of historic structures. We definitely need more experimental data for the proper exploring of the relation between the different measurement values. In that case, there might be a chance for example to establish new calibration curve for the estimation of strength based on hardness values. As a next step, a large-scale study could be conducted for the better understanding of the strength behavior of historic wrought iron building structure elements.

\section{Acknowledgement}

Special thanks for the support of the research to Dr. Lajos Imre, senior research officer at ÉMI Kht., Dr. Tamás Mezős professor of Budapest University of Technology and Economics, associates of the Department of Applied Mechanics of Budapest University of Technology and Economics, Ferenc Gerzsenyi and staff members at the Material Testing Laboratory of CSÖSZER zRt., Mr. Géza Sóti and staff members at the Steel Testing Laboratory of MÁV Felépítményvizsgáló Kht. and Mr. Zoltán Takács and Mr. Károly Félegyházy smith artists.

\section{References}

[1] O'Sullivan, M., Swailes, T. "Study of Historical Test Data for Better Informed Assessment of Wrought Iron Structures". International Journal of Architectural Heritage, 3(4), pp. 260-275. 2009.

https://doi.org/10.1080/15583050902802337

[2] L'Heriter, M., Dillmann, P. "Fer ou acier? Caractérisation des alliagesferreuxutilisésdans la construction des églisesgothiques au MoyenÂgeet à la périodemoderneL'exemple de Troyes et de Rouen". (Iron or steel? Characterization of old iron used in the constructions of the gothic churches in the Middle Age and in the modern times on the bases of the examples of Troyen and Rouen.) pp. 263-281. In : L'acieren Europe avant Bessemer (The steel before Bessemer) - Séries Histoire et Technique. (Dillmann, P., Pérez, L., Verna, C. (Eds.)), CRNS-Université Toulouse-Le Mirail, Toulouse, 2011. (in French).

[3] Gordon, R., Knopf, R. "Evaluation of Wrought Iron for Continued Service in Historic Bridges". Journal of Materials in Civil Engineering, 17(4), 393-399. 2005. https://doi.org/10.1061/(ASCE)0899-1561(2005)17:4(393)

[4] Buchwald, V. F., Wivel, H. "Slag Analysis as a Method for the Characterization and Provenancing of Ancient Iron Objects". Materials Characterization 40(2), 73-96. 1998.

https://doi.org/10.1016/S1044-5803(97)00105-8

[5] Cecchetti, F., Sassu, M. "Construction Evolution of Medieval Tuscan Monasteries, The Tie Beam System in the Sant' Agostino Monastery at Nicosia (Pisa)." In Proceedings of the First International Congress on Construction History, ed. Heurta, S., Madrid, January 20-24, Instituto Juan de Herrera, SEHC, COAC, CAATC, Madrid, pp. 551-558. 2003. http://www.sedhc.es/biblioteca/actas/CIHC1_054_Cecchetti\%20F.pdf

[6] Grueber, B. "Allgemeine Baukunde". (General Construction Science) Berlin, 1863. (in German).

[7] Gottgetreu, R. "Physische und chemische Beschaffenheit der Baumaterialien". (Physical and Chemical Nature of Building Materials). Berlin, Julius Springer, 1881. (in German).

[8] Ledebur, A. "Eisen und Stahl". (Iron and Steel) S. Fisher Verlag, Berlin, 1890. (in German).

[9] Maurer, M. "A vasfajok, különös tekintettel a hídépítéshez használt vasfajok szilárdsági viszonyaira". (Kinds of Iron with Special Regard to the Strength of the Irons used to Bridge Constructions.) Magyar Mérnök és Épitész Egylet Közlönye, 26, 196-198. 1892. (in Hungarian). 
[10] Janke, A. "Lehrbuch der Baumaterialien". (Coursebook for Building Materials). Köln, Paul Reubner, 1895. (in German).

[11] Grofcsik, J. "Épitöipari Anyagtan". (Construction Industrial Material Science). Budapest, Atheneum, 1922. (in Hungarian).

[12] Nemeskéri Kiss, G. "Hegeszvas szerkezetű vasúti hidak anyagának minőségi vizsgálatai". (Testing Material Quality of Wrought Iron Railway Bridges) Mélyépitéstudományi Szemle, 8, 29-46. 1958. (in Hungarian)

[13] Papp, T. "Hegesztett vasból készült vasúti hidak anyagvizsgálati eredményeinek értékelése". (Evaluation of Material Test Results of Wrought Iron Railway Bridges.) Mélyépitéstudományi Szemle, 9, 24-39. 1959. (in Hungarian).

[14] Heinzerling, F. "Construction-Elemente - Handbuch der Architektur". (Construction Elements - Handbook of the Architecture) Part 3 - Volume 1, Darmstadt, Diehl, 1886. (in German).

[15] Holzer, S. M., Köck, B. "On the Use of Iron Elements in Southern Bavarian Roofs of the Baroque". In: Proceedings of the Third International Congress on Construction History, (Kurrer, K-E. (Ed.)), Cottbus, May 20-24, Neunplus1, Berlin, pp. 821-828. 2009.
[16] Haas, W. "Hölzerne und eiserne Ankern an mittelalterlichen Kirchenbauten". (Timber and Iron Tie-beams in Medieval Church Constructions). Architectura - Zeitschrift für Geschichte der Baukunst, 13, 136-151. 1983. (in German).

[17] Barkhausen, G., Körner C. "Raumgebende Constructionen - H. Balkendecken., Gewölbte Decken". Handbuch der Architektur. (Spacious constructions - T. Beam Slabs, Vaulted Ceilings - Handbook oft the Architecture). Part 3 - Volume 2 - Fascicle 3, Darmstadt, Bergsträsser, 1895. (in German).

[18] Gordon, R. "Process Deduced From Ironmaking Wastes and Artefacts". Journal of Archeological Science, 24, 9-18. 1997. https://doi.org/10.1006/jasc.1995.0092

[19] Sparks, S.P. "Evaluation of iron and steel in historic bridges". In: Structural Analysis of Historic Construction. pp. 451-458, Taylor \& Francis Group, London. 2008. http://www.sparksengineering.com/wp-content/ uploads/downloads/2013/05/Evaluation-of-Iron-and-Steel-in-HistoricBridges-P-Sparks.pdf 